

\title{
THE BRITISH SCHOOL AT ATHENS
}

REGISTERED CHARITY NO. 208673

\author{
www.bsa.ac.uk \\ PATRON \\ HRH The Prince of Wales \\ CHAIR OF COUNCIL \\ Professor M. Schofield F.B.A. \\ DIRECTOR \\ Professor C.A. Morgan, MA, PhD
}

The British School at Athens, an educational charity founded in 1886, forms part of the British Academy's network of Sponsored Institutes and Societies (BASIS), which sustains and supports research overseas. The School promotes research of international excellence in all disciplines pertaining to Greek lands, from fine art to archaeometry, and in all periods to modern times. It does so through:

- a programme of research undertaken both alone and in collaboration with UK-based and other overseas institutions;

- an academic programme of seminars, lectures, and conferences;

- its internationally renowned library;

- the work of the Fitch Laboratory in science-based archaeological research across the Mediterranean;

- supporting the work of individual researchers from the UK and elsewhere, including applications for study and fieldwork permits; advice on the development of research programmes; accommodation and facilities in Athens and Knossos; and provision of online services;

- making their work known through the publication of its journals and monograph series;

- promoting the use of its archival, laboratory, and museum collections by the scholarly community worldwide;

- providing funding (including studentships and visiting fellowships) for research in Greece, and to enable Greek researchers to visit the UK;

- providing internships and training courses for undergraduates, postgraduates, and schoolteachers.

$\begin{array}{llll}\text { Athens: } & \begin{array}{l}\text { Odos Souedias 52 } \\ \text { GR-106 76 Athens } \\ \text { Greece }\end{array} & \text { School Office: } & \text { Tel: 0030-210-721 0974 } \\ \text { Lax: 0030-210-723 6560 } & & \text { E-mail: admin@bsa.ac.uk } \\ \text { London: } & \begin{array}{l}\text { The British Academy } \\ \text { 10-11 Carlton House Terrace } \\ \text { London SW1Y 5AH }\end{array} & \text { London Office: } & \text { Tel: 0044-(0)20-7969-5315 } \\ \text { E-mail: bsa@bsa.ac.uk }\end{array}$

Information for contributors to the Annual, including style guidelines, may be found at journals.cambridge.org/ath

The Annual of the British School at Athens is published by Cambridge University Press for the British School at Athens.

INDIVIDUAL SUBSCRIBERS

Individuals receive the Annual as part of membership of the School: further information on membership may be found at www.bsa.ac.uk.

\section{INSTITUTIONAL SUBSCRIPTION RATES}

The Annual of the British School at Athens (ISSN 0068-2454) is published once a year in December. The subscription price (excluding VAT) of volume 106 (2011), which includes print and online access, is $£ 84$ net (US\$137 in the USA, Canada and Mexico) for institutions. EU subscribers (outside the UK) who are not registered for VAT should add VAT at their country's rate. VAT-registered customers should provide their VAT registration number. Japanese prices for institutions (including ASP delivery) are available from Kinokuniya Company Ltd., P.O. Box 55, Chitose, Tokyo 156, Japan. All prices include delivery by air where appropriate.

Orders, which must be accompanied by payment, may be sent to a bookseller, subscription agent or direct to the publisher: Cambridge University Press, The Edinburgh Building, Shaftesbury Road, Cambridge CB2 8RU; or in the USA, Canada and Mexico: Cambridge University Press, Journals Fulfillment Department, 100 Brook Hill Drive, West Nyack, New York $10994-$ 2133, USA.

\section{COPYING}

This journal is registered with the Copyright Clearance Center, 222 Rosewood Drive, Danvers, MA 01923, USA. Organisations in the USA who are registered with the C.C.C. may therefore copy material (beyond the limits permitted by sections 107 and 108 of the U.S. Copyright law) subject to payment to the C.C.C. of the per copy fee of $\$ 30$. This consent does not extend to multiple copying for promotional or commercial purposes. Code 0068-2454/2011. ISI Tear Sheet Service, 3501 Market Street, Philadelphia, PA 19104, USA, is authorised to supply single copies of separate articles for private use only. Organisations authorised by the Copyright Licensing Agency may also copy material subject to the usual conditions. For all other use, permission should be sought from Cambridge or from the North American Branch of Cambridge University Press.

The journal is included in the Cambridge Journals Online service which can be found at http://journals.cambridge.org.

This journal has been printed on FSC-certified paper and cover board. FSC is an independent, non-governmental, non-for-profit organisation established to promote the responsible management of the world's forests. Please see www.fsc.org for information.

(C) The British School at Athens, 2011 


\section{THE ANNUAL OF THE \\ BRITISH SCHOOL AT ATHENS \\ NO. 106 \\ 2OII}

Published by Cambridge University Press

on behalf of the Council of the British School at Athens 
(C) The Council, British School at Athens, 20I I ISSN 0068-2454 


\section{Contents}

Alan Johnston, To the Reader

James Whitley, Praisos V: A Preliminary Report on the 2007 Excavation Season

A. Quercia, A. Johnston, A. Bevan, J. Conolly and

A. Tsaravopoulos, Roman pottery

from an intensive survey of Antikythera, Greece

Žarko Tankosić and Iro Mathioudaki (With a contribution on lithics by Catherine Perlès), The finds from the prehistoric site of Ayios Nikolaos Mylon, southern Euboea, Greece

JosepH W. SHaw, Tracing the ancestry of the Minoan Hall system

YanNis Galanakis, An unpublished stirrup jar from Athens and the $187 \mathrm{I}-2$ private excavations in the Outer Kerameikos

ERophile Kolia, A sanctuary of the Geometric Period in ancient Helike, Achaea (With an appendix by Eleni Psathi)

Anastasia Gadolou, A Late Geometric architectural model with figure decoration from Ancient Helike, Achaea

Andrei OpatT ANd Aris Tsaravopoulos, Amphorae of Dressel 24 similis type in the central Aegean area (Chios-Erythrai-Kyme)

Deborah Harlan, British Lancastrian schools of nineteenth-century Kythera

INDEXES 